\title{
Control Design for Shunt Active Power Filter Based on p-q Theory in Photovoltaic Grid-Connected System
}

\author{
Moh. Jauhari' ${ }^{1}$, Dedet Candra Riawan², Mochamad Ashari ${ }^{3}$ \\ ${ }^{1}$ Department of Industrial Electric Engineering, Politeknik Negeri Madura (Poltera), Indonesia \\ ${ }^{2,3}$ Department of Electrical Engineering, Institut Teknologi Sepuluh Nopember (ITS) Surabaya, Indonesia
}

\begin{abstract}
Article Info
Article history:

Received Jan 30, 2018

Revised Jul 23, 2018

Accepted Aug 6, 2018

\section{Keyword:}

Photovoltaic

p-q Theory

Reference current

SAPF

THD

ABSTRACT

This paper presents the control for Shunt Active Power (SAPF) filter in photovoltaic (PV) systems connected to the grid. The proposed configuration of the system consists of a photovoltaic array that connected to the grid through the three-phase inverter topology that also serves as an active filter. Photovoltaic is coupled in parallel with the direct curret (DC) side of the active filter. With this configuration, can be obtained three advantages, namely the elimination of harmonic currents caused by nonlinear load, reactive power injection, and injection of active power generated photovoltaic. The $\mathrm{p}-\mathrm{q}$ Theory is used to calculate the harmonic reference current to be used to control the active filter coupled fotovoltaic in generating anti-harmonic currents. The results show that system can reduce harmonic distortion from THD $27.22 \%$ to be THD $1.05 \%$, whereas when the active power from photovoltaic injected, the THD become $2.01 \%$. Power sharing can also be seen from this study.
\end{abstract}

Copyright (C) 2018 Institute of Advanced Engineering and Science. All rights reserved.

\section{Corresponding Author:}

Moh. Jauhari,

Departement of Industrial Electric Engineering,

Politeknik Negeri Madura,

Jl. Raya Camplong km. 4, Taddan, Camplong, Sampang, East Java, Indonesia.

Email: mohjauhari51@gmail.com

\section{INTRODUCTION}

The development of power electronics equipment that used as an interface between the load and the electrical system affects the power quality in particular the emergence of electrical harmonics [1]. the power electronics converter is a nonlinear load that injects the harmonic current on the grid. the non linear load is the main cause of harmonic distortion that occurs in the electrical system. Variable Speed Drives (VSD), Uninterruptible Power Supply (UPS), Switched Mode Power Supply (SMPS) [2].

Harmonic distortion causes some unexpected conditions on the electrical system. Harmonic distortion can decrease the accuracy of the electrical meter. Harmonic distortion may also cause excessive dissipation of electrical equipment so as to increase the cost of the bill. Furthermore, harmonic distortion causes electrical equipment not to work on the specified power quality standards causing a decrease in the lifetime of the electrical equipment [3].

Passive filter is one method used to reduce current harmonic distortion. These passive filters use a combination of inductors and capacitors to eliminate harmonics at a predetermined frequency. The drawback of this is a passive filter harmonic compensation provided is fixed, so it can not eliminate the frequency harmonics that are not specified [4]. Active Power Filter (APF) has advantages that can eliminate various frequency harmonics that arise. In active power filter, there are an inverter and controllers to control the compensation current to eliminate the harmonic currents distortion that arise [5]-[6]. Shunt active power filter (SAPF) arranged in parallel with the non-nilier load. The shunt active power filter has advantages in dimension than in series type [7]. 
The p-q Theory introduced by Professor Akagi in 1983 [8]. This Theory explains the concept of active and reactive power in the instantaneous calculation algorithm. Than, the $\mathrm{p}-\mathrm{q}$ Theory developed in the application of power flow calculations and harmonic distorted component calculations to determine the reference current [9]-[11].

The generation of reference current of active power filter influenced by the performance of active power filter control system in response to the load changes. Closed-loop control proportional-integral (PI) is used to regulate DC side voltage and power flow of active power filter [12]-[14]. The use of closed-loop control systems improve the accuracy of p-q Theory in the generation of the reference current in the range of larger currents.

Research and development of photovoltaic grid-connected systems has increased very significantly in the last two centuries. Three-phase inverter Sinusoidal Pulse width modulation (SPWM) control system used to transfer active power that generated by photovoltaic into the grid [15]-[18].

This paper, photovoltaic coupled in parallel with the shunt active power filter so that with this system, the shunt active power filter not only can reduce harmonic currents but also can supply the active power that generated by photovoltaic. P-q theory is used to control active power filters in determining harmonic reference currents.

The contribution of this paper is to combine the functions of an active power filter into the photovoltaic grid-connected systems so that by the proposed design system, it will be obtained three advantages, namely harmonic current compensation, reactive power compensation, and the of active power compensation that generated by photovoltaic. Basic p-q Theory is modified to perform the function of active power compensation. Photovoltaic array voltage is increased by using quadratic boost converter with a voltage conversion ratio is relatively larger than conventional boost converter.

\section{SYSTEM DESIGN}

\subsection{Shunt Active Power Filter In Photovoltaic Grid-Connected System}

The active power filter design on Photovoltaic Grid-Connected System consists of two main components, namely the shunt active power filter which are arranged in parallel with a nonlinear load, and photovoltaic that arranged in parallel with the DC side voltage of the Voltage Source Inverter (VSI). Active power filter serves to eliminate harmonics at the source based on the control system that used. In addition, the active filter also serves to compensate for reactive power into the load [19]. Active power filter coupled photovoltaic can inject active power to be supplied into the grid. Notation SAPF+PV show shunt active filter system coupled photovoltaic.

Figure 1 shows the configuration of the filter active in photovoltaic grid-connected system. Active power filters coupled photovoltaic connected to the distribution network through a Point of Common Coupling (PCC) through the LF inductor. The LF Inductor is not as inductor for passive filter but as an inductor coupling that serves as a filter switching VSI [20].

The DC voltage at the photovoltaic array is connected to the DC-DC to obtain high DC voltage [21]-[22]. Quadratic converter is used as a DC-DC converter because the ratio of input and output voltages are relatively large [23]. The layout of inductors, capacitors, diodes, and switch on quadratic boost converter as shown in Figure 2. Correlation of the input and output voltage of quadratic boost converter as in the following Equation (1):

$$
\frac{\mathrm{v}_{\text {out }}}{\mathrm{v}_{\text {in }}}=\frac{1}{(1-\mathrm{D})^{2}}
$$

where $\mathrm{D}$ is the duty cycle.

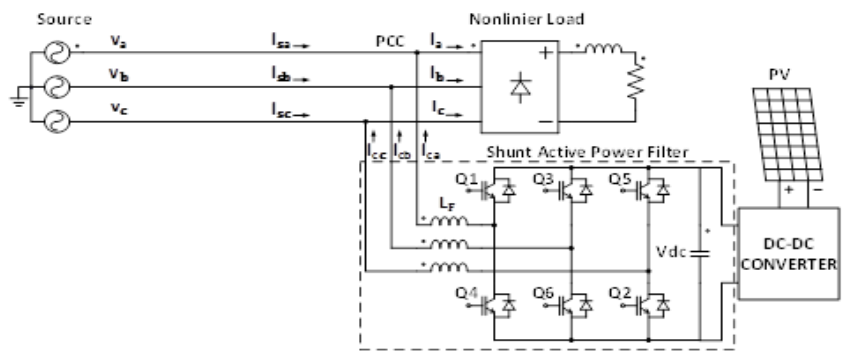

Figure 1. Effects of selecting different switching under dynamic condition 


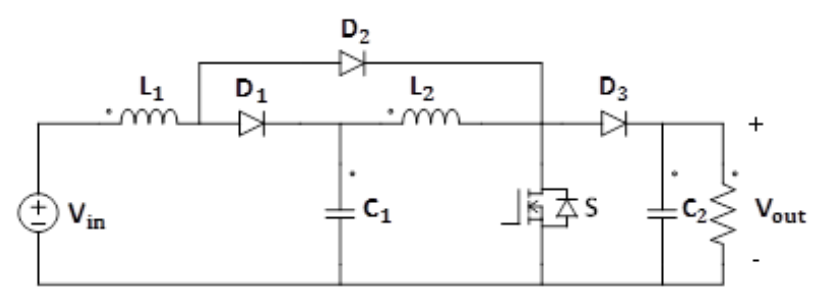

Figure 2. Quadratic converter topology

\subsection{Control System On The Shunt Active Power Filter Coupled Photovoltaic}

The $\mathrm{p}-\mathrm{q}$ Theory is used to calculate the reference current of shunt active power filter. Reference current is a signal current waveform of the anti-harmonics current. Than, the Reference current is used to control the switching pattern of shunt active power filter so that anti-harmonic current can be generated. Anti-harmonic current waveform is used to eliminate the harmonic current waveform.

The first step in the calculation of the reference current generation is to transform the three-phase voltages and currents in abc coordinates into two phases in $\alpha \beta$ coordinates using clarke transformation. This transformation is necessary to simplify the calculation of instantaneous power at a later stage [24]. Equation (2) shows the Clarke transformation of voltage while equation (3) shows the current clarke transformation.

$$
\begin{aligned}
& {\left[\begin{array}{c}
\mathrm{V}_{\alpha} \\
\mathrm{V}_{\beta}
\end{array}\right]=\sqrt{\frac{2}{3}}\left[\begin{array}{ccc}
1 & \frac{-1}{2} & \frac{-1}{2} \\
0 & \frac{\sqrt{3}}{2} & \frac{\sqrt{3}}{2}
\end{array}\right]\left[\begin{array}{c}
\mathrm{V}_{\mathrm{a}} \\
\mathrm{V}_{\mathrm{b}} \\
\mathrm{v}_{\mathrm{c}}
\end{array}\right]} \\
& {\left[\begin{array}{c}
\mathrm{I}_{\alpha} \\
\mathrm{I}_{\beta}
\end{array}\right]=\sqrt{\frac{2}{3}}\left[\begin{array}{ccc}
1 & \frac{-1}{2} & \frac{-1}{2} \\
0 & \frac{\sqrt{3}}{2} & \frac{\sqrt{3}}{2}
\end{array}\right]\left[\begin{array}{c}
\mathrm{I}_{\mathrm{a}} \\
\mathrm{I}_{\mathrm{b}} \\
\mathrm{I}_{\mathrm{c}}
\end{array}\right]}
\end{aligned}
$$

Based on the $p-q$ Theory, instantaneous active and reactive power can be expressed in a multiplication operation voltages and currents in the $\alpha \beta$ coordinates as in Equation (4).

$$
\left[\begin{array}{l}
\mathrm{p} \\
\mathrm{q}
\end{array}\right]=\left[\begin{array}{cc}
\mathrm{v}_{\alpha} & \mathrm{v}_{\beta} \\
-\mathrm{v}_{\beta} & \mathrm{v}_{\alpha}
\end{array}\right]\left[\begin{array}{c}
\mathrm{I}_{\alpha} \\
\mathrm{I}_{\beta}
\end{array}\right]
$$

Instantaneous power $\mathrm{p}$ and $\mathrm{q}$ in equation (4) consists of the $\mathrm{AC}$ component ( $\mathrm{p} \sim$ and $\mathrm{q}$ ) and the DC component ( $\mathrm{P}$ and $\mathrm{Q})$. DC components are fundamental components while the $\mathrm{AC}$ component is a harmonic component, so that:

$$
\left[\begin{array}{l}
\mathrm{p} \\
\mathrm{q}
\end{array}\right]=\left[\begin{array}{l}
\mathrm{P}+\mathrm{p} \sim \\
\mathrm{Q}+\mathrm{q} \sim
\end{array}\right]
$$
obtained:

To calculate the current value of the equation (4), the equation is reversed, so that would be

$$
\left[\begin{array}{l}
\mathrm{I}_{\alpha} \\
\mathrm{I}_{\beta}
\end{array}\right]=\frac{1}{\mathrm{v}_{\alpha}{ }^{2}+\mathrm{v}_{\beta}{ }^{2}}\left[\begin{array}{cc}
\mathrm{v}_{\alpha} & -\mathrm{v}_{\beta} \\
\mathrm{v}_{\beta} & \mathrm{v}_{\alpha}
\end{array}\right]\left[\begin{array}{l}
\mathrm{p} \\
\mathrm{q}
\end{array}\right]
$$

Figure 3 shows the calculation step of $\mathrm{p}-\mathrm{q}$ Theory in generating a reference current signal. The voltage and current on the source side is read by the sensor is then used as input for the calculation of the reference current generation. The reference current is then compared with the current compensation of active power filter using hysteris current control method to produce a switching pattern on the VSI of active power filter.

From Equation (5) and Equation (6) can be seen that for eliminating reactive power from the source is to making negative value of $\mathrm{q}$ in equation (6). To separate the harmonic component to the fundamental component, p power only use the AC components. Then the $\mathrm{P}_{\mathrm{PV}}$ power of the photovoltaic added. Power losses in the VSI is represented as $\mathrm{P}_{\text {loss. }}$ so that the reference current is: 


$$
\left[\begin{array}{c}
\mathrm{I}_{\mathrm{c} \alpha^{*}} \\
\mathrm{I}_{\mathrm{c} \beta^{*}}
\end{array}\right]=\frac{1}{\mathrm{v}_{\alpha}{ }^{2}+\mathrm{v}_{\beta}{ }^{2}}\left[\begin{array}{cc}
\mathrm{v}_{\alpha} & -\mathrm{v}_{\beta} \\
\mathrm{v}_{\beta} & \mathrm{v}_{\alpha}
\end{array}\right]\left[\begin{array}{c}
\mathrm{p} \sim-\mathrm{P}_{\text {loss }}+\mathrm{P}_{\mathrm{PV}} \\
-\mathrm{q}
\end{array}\right]
$$

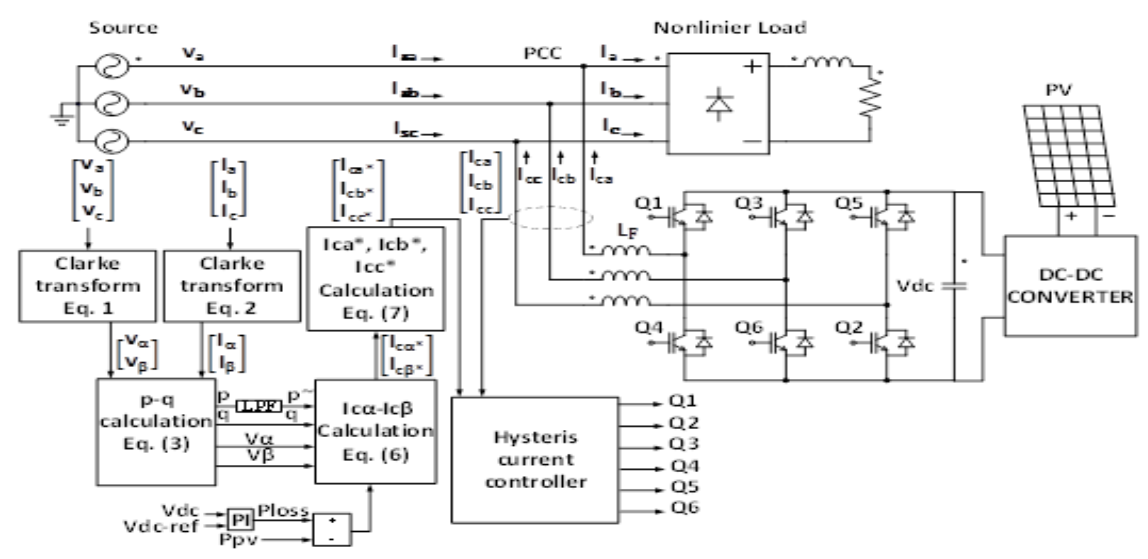

Figure 3. Block diagram of p-q Theory calculation

Reference current in Equation (7) is then transformed from the $\alpha \beta$ coordinates into $a b c$ coordinate with Equation (8):

$$
\left[\begin{array}{l}
\mathrm{I}_{\mathrm{ca}^{*}} \\
\mathrm{I}_{\mathrm{cb}^{*}} \\
\mathrm{I}_{\mathrm{cc}}
\end{array}\right]=\sqrt{\frac{2}{3}}\left[\begin{array}{cc}
1 & 0 \\
\frac{-1}{2} & \frac{\sqrt{3}}{2} \\
\frac{-1}{2} & \frac{-\sqrt{3}}{2}
\end{array}\right]\left[\begin{array}{l}
\mathrm{I}_{\mathrm{c} \alpha^{*}} \\
\mathrm{I}_{\mathrm{c} \beta^{*}}
\end{array}\right]
$$

\subsection{Parameter}

Table 1 shows the parameters that used in the simulation of shunt active power filter in the active filter in photovoltaic grid-connected system.

Table 1. The Parameter Value of Shunt Active Power Filter Coupled Photovoltaic

\begin{tabular}{ll}
\hline Parameters & Value \\
\hline $\mathrm{V}_{\text {Source }}$ & $3 \phi 380$ volt \\
frequency & $50 \mathrm{~Hz}$ \\
Load & 6-pulsa rectifier 1700 watt, 10 var \\
$\mathrm{V}_{\mathrm{DC}}$ & 850 volt \\
DC-link capacitor & $20 \mathrm{uF}$ \\
$\mathrm{L}_{\mathrm{F}}$ Inductor & $55 \mathrm{mH}$ \\
PV $_{\mathrm{PV}}$ & $250 \mathrm{watt}$ \\
PI constans & $\mathrm{K}_{\mathrm{p}}=10, \mathrm{~K}_{1}=15$ \\
Converter component & $\mathrm{L}_{1}=25 \mu \mathrm{H}, \mathrm{L}_{2}=150 \mu \mathrm{H}$, \\
& $\mathrm{C}_{1}=68,544 \mu \mathrm{F}, \mathrm{C}_{2}=52,735 \mu \mathrm{F}$ \\
\hline
\end{tabular}

\section{RESULT AND ANALYSIS}

$\mathrm{SAPF}+\mathrm{PV}$ system configuration as shown in Figure 2 is simulated with MATLAB / Simulink to determine the performance of the system. Time sampling is $0.000006 \mathrm{~s}$. The scenario which was performed during the simulation includes, power flows from the source, PV and load. Simulations time line performed during $0.2 \mathrm{~s}$. For the firs $0.1 \mathrm{~s}$, the system is operated as pure SAPF then for the next second power from PV is injected.

\subsection{Active Power And Reactive Power Of Shunt Active Power Filter In Photovoltaic Grid-Connected System}

Shunt active power filter coupled photovotaic actively controlled in order to supply the active and reactive power to the load or to the grid. Simulations conducted under a constant load 1700 watts and 210 
var. The system serves as a pure SAPF at $\mathrm{t}=0.02 \mathrm{~s}$ until $\mathrm{t}=0.1 \mathrm{~s}$, during this period, all of the needs of active power served by the source. Then in the period $t=0.1 \mathrm{~s}$ to $\mathrm{t}=0.2 \mathrm{~s}$, photovoltaic power is injected so that the needs of active power is supplied by photovoltaic. As for the reactive power, all the needs of the load served by the shunt active power filter. Figure 4 and Figure 5 respectively show the relationship between the active and reactive power of source, load, and $\mathrm{SAPF}+\mathrm{PV}$. The simulation results show that the SAPF+PV systems are already able to control the power flow of active and reactive power.

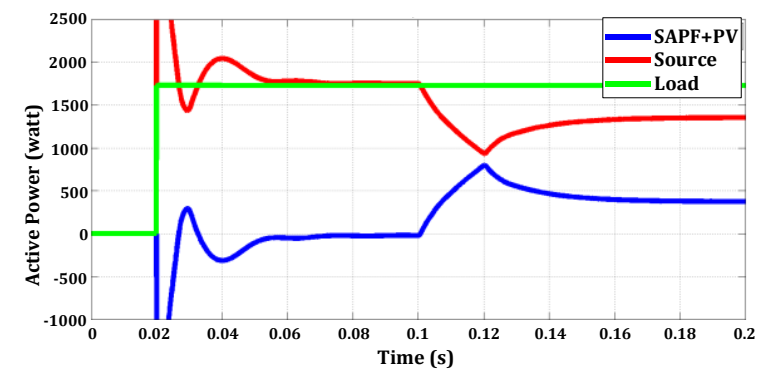

Figure 4. Active power curve of source, load and $\mathrm{SAPF}+\mathrm{PV}$

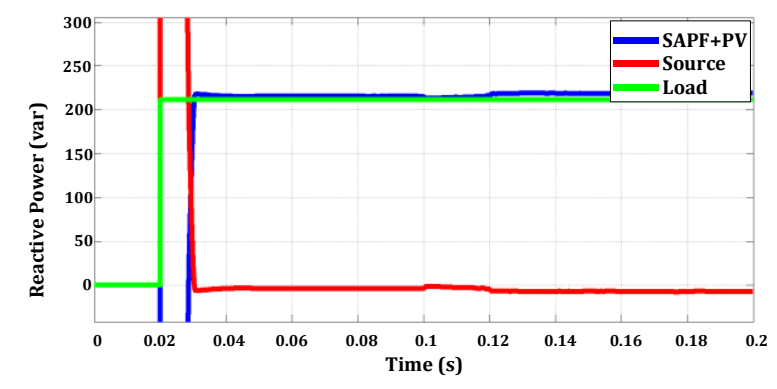

Figure 5. Reactive power curve of source, load and $\mathrm{SAPF}+\mathrm{PV}$

\subsection{The Dc Side Voltage Of Of Shunt Active Power Filter In Photovoltaic Grid-Connected System}

In accordance with the design, the DC side voltage is kept constant at a reference voltage of 850 volts. Figure 6 shows the DC side voltage can be kept constant according to the voltage reference despite the process of photovoltaic power injection at $t=0.1 \mathrm{~s}$. it indicates that the $\mathrm{DC}$ side voltage regulator is already working optimally.

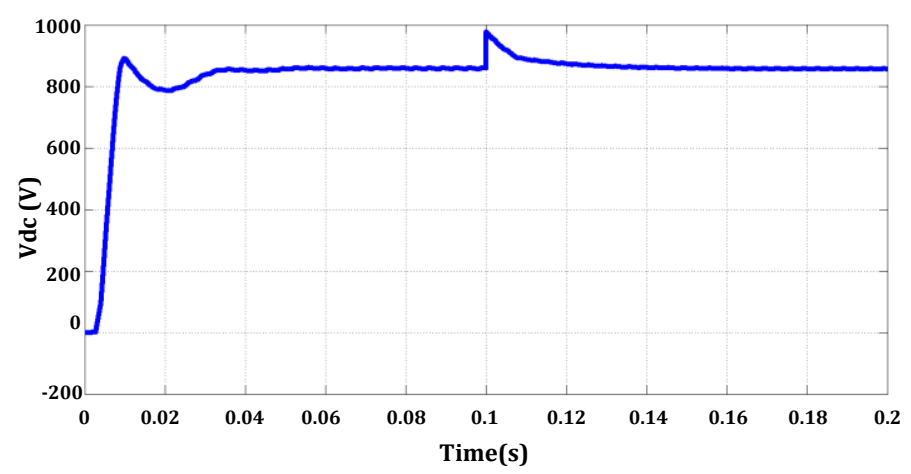

Figure 6. The DC side voltage of SAPF+PV

\subsection{Shunt Active Power Filter Simulation In Photovoltaic Grid-Connected System}

Figure 7 shows the simulation results of the shunt active power filter active in photovoltaic gridconnected system. The voltage that used in the calculation of the reference current is the voltage of each phase. compensation results show that the current resources has been a pure sinusoidal. In addition, the compensation current waveform is different at the time of photovoltaic injected active power into the grid. 


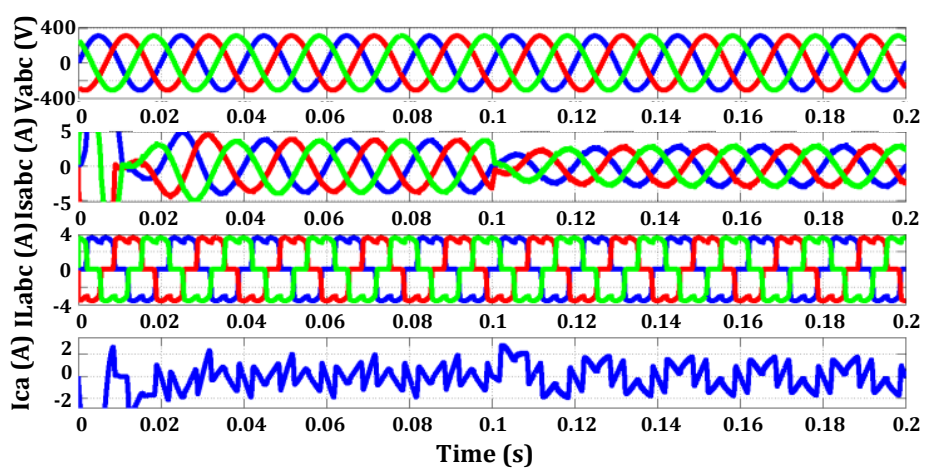

Figure 7. Simulation results of the shunt active power filter active in photovoltaic grid-connected system

In this study, analysis of harmonic component content is done by using Fast Fourier Trasform (FFT) Analysis with the maximum frequency that used in the calculation of Total Hamonic Distorsion (THD) is $1000 \mathrm{~Hz}$. The magnitude of the fundamental component and harmonic components expressed in percent units. The magnitude of the first order or the fundamental frequency would be $100 \%$, which is the largest magnitude, whereas in the other order will be smaller than the first order. Figure 8-10 shows the harmonic spectrum in the time before and after compensated.

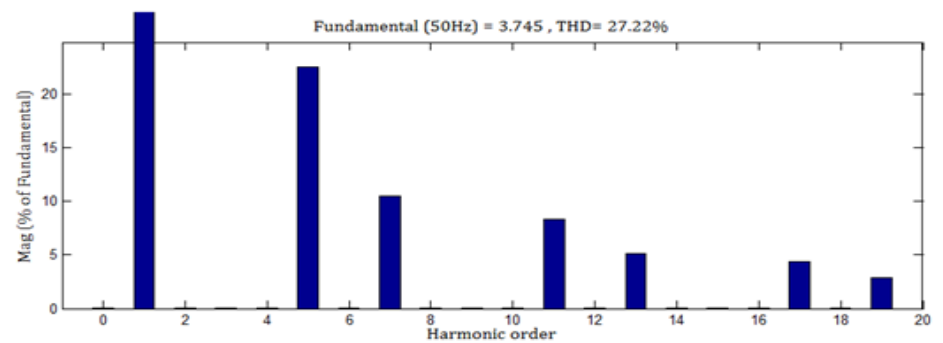

Figure 8. THD of current source before compensated

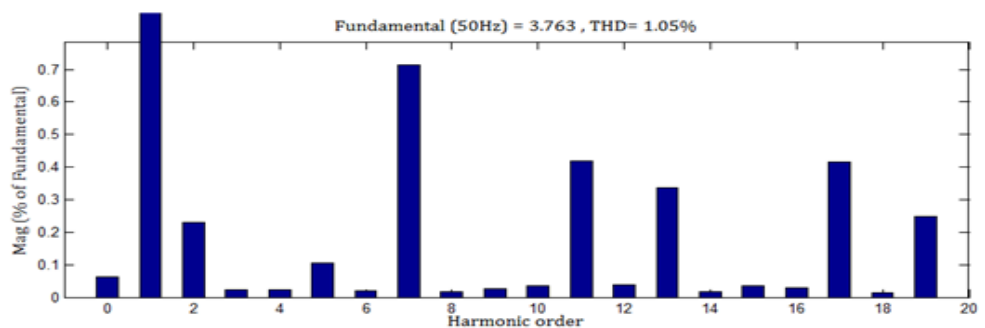

Figure 9. THD of current source before compensated in pure SAPF mode

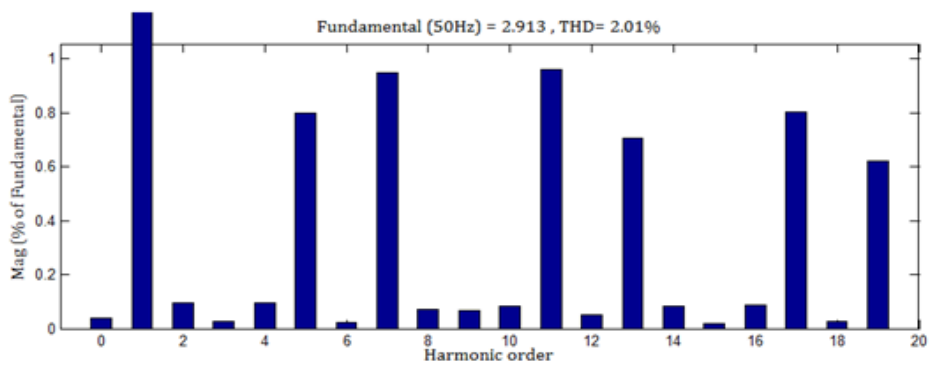

Figure 10. THD of current source before compensated in SAPF+PV mode 
From the simulation results, the THD of current source before compensated is $27.22 \%$ as shown in Figure 8. Meanwhile, after the compensated, the THD of current source is $1.05 \%$ when the system is operating as a pure SAPF as shown in Figure 9. When SAPF coupled with PV, the THD of current source is $2.01 \%$ as shown in Figure 10.

\section{CONCLUSION}

In this paper, the design of shunt active power filter based on $\mathrm{p}-\mathrm{q}$ Theory in photovoltaic gridconnected system has been proposed. The p-q Theory is used to calculate the reference current. From the simulation results, can be obtained some key points as follows:

a Vdc voltage can be kept constant corresponding reference voltage of 850 Volt.

b Control of active and reactive power flow can work according to the p-q Theory.

c SAPF+PV systems are designed to reduce the value of THD that generated by 6-pulse rectifier 1700 Watt from $27.22 \%$ to $1.05 \%$. While, when the active power from photovoltaic is injected, the THD becomes $2.01 \%$.

\section{REFERENCES}

[1] Popescu, M. Bitoleanu, Alexandru. Suru, Vlad, “A DSP-Based Implementation of the-Theory in Active Power Filtering under Nonideal Voltage Conditions," IEEE Transactions on Industrial Informatics, vol. 9, no. 2, hal. 880889, 2013.

[2] M. Kala, N. Rathina Prabha., " Grid Interconnected Photo Voltaic System Using Shunt Active Filter for Power Quality Improvement, "International Journal of Power Electronics and Drive Systems (IJPEDS), vol. 9, pp. 365376, 2018.

[3] M. Grady, W. Santoso, "Understanding power system harmonics," IEEE Power Eng. Rev., vol. 21, no. 11, pp. 8-11, 2001.

[4] J.C. Das, "Passive filters - potentialities and limitations," IEEE Trans. on Industry Applications, Vol. 40. No.1, pp.232-241, 2004.

[5] Petit, F. J. Robles, Guillermo. Amarís, Hortensia, "Current Reference Control for Shunt Active Power Filters under Nonsinusoidal Voltage Conditions," IEEE Transactions on Power Delivery, vol. 22, no. 4, hal. 2254-2261, 2007.

[6] Abdallah B., Othmane A., Ahmed A, Abdelmalek M., " Experimental Validation of Single Phase Series Active Power Filter Using Fuzzy Control Technique, "International Journal of Power Electronics and Drive Systems (IJPEDS), vol. 9, pp. 591-601, 2018.

[7] M. I. Montero, E.R. Kadaval, F. B. Gonzalez, "Comparison of Control Strategies for Shunt ActivePower Filters in Three-Phase Four-Wire Systems,” IEEE Trans. On Power Elec., vol. 22, no. 1, 2007.

[8] Akagi, H., Kanazawa, Y., and Nabae, "A., Instantaneous reactive power compensators comprising switching devices without energy storage components," IEEE Trans. Ind. Appl., vol. 20, no. 3, hal. 625-630, 1984.

[9] J. L. Willems, "A new interpretation of the Akagi-Nabae power components for nonsinusoidal three-phase situations," IEEE Trans. Instrum. Meas., vol. 41, no. 4, pp. 523-527, Aug. 1992.

[10] H. Akagi, H. Watanabe, and M. Aredes, "Shunt active filters, in Instantaneous Power Theory and Applications to Power Conditioning," New York: Wiley-IEEE Press, pp. 109-220. 2007.

[11] M. P. Kazmierkowski, M. Jasinski, and G. Wrona, "DSP-based control of grid-connected power converters operating under grid distortions," IEEE Trans. Ind. Inf., vol. 7, no. 2, pp. 204-211, May 2011.

[12] Y. Han, L. Xu, M. M. Khan, C. Chen, G. Yao, and L. D. Zhou, "Robust deadbeat control scheme for a hybrid APF with resetting filter and ADALINE-based harmonic estimation algorithm," IEEE Trans. Ind. Electron., vol. 58, no. 9, pp. 3893-3904, Sep. 2011.

[13] A. Bhattacharya and C. Chakraborty, "A shunt active power filter with enhanced performance using ANN-based predictive and adaptive controllers," IEEE Trans. Ind. Electron., vol. 58, no. 2, pp. 421-428, Feb. 2011.

[14] J. Liu, P. Zanchetta, M. Degano, and E. Lavopa, "Control design and implementation for high performance shunt active filters in aircraft power grids," IEEE Trans. Ind. Electron., vol. 59, no. 9, pp. 3604-3613, Sep. 2012.

[15] Lei Wang, Shuanghui Hao, Minghui Hao, Baoyu Song, "A hybrid PWM strategy combining modified space vector and sinusoidal pulse width modulation methods," Intelligent Control and Automation (WCICA) 2014 11th World Congress on, pp. 4431-4434, 2014.

[16] A. Justus, "High efficient power electronic inverter topology with SPWM technique for single phase trasformerless utility interactive photovoltaic system," 2014 ICICES, pp. 1-6, 2014.

[17] P. C. Tan and Z. Salam, "A new single-phase two-wire hybrid active power filter using extension p-q theorem for photovoltaic application," in Proc. National Power and Energy Conference, PECon, Malaysia, hal. 126-131, 2004.

[18] Z. Yang, H. Li, C. Fang, B. Zhu, B. Zhang, "Common-mode electromagnetic interference calculation method for a PV inverter with chaotic SPWM," Magnetics Conference (INTERMAG) 2015 IEEE, pp. 1-1, 2015

[19] M. Jauhari, D.C. Riawan, M. Ashari, "Design of Digital Controller for Active Power Filter Based on p-q Theory," proceeding of International conference on engineering and natural scienc (ICENS), Malaysia, pp. 39-42, 2016.

[20] H. Akagi, “Active harmonic filters," Proceedings of the IEEE, vol. 93, pp. 2128-2141, 2005. 
[21] Oswaldo Lopez-Santos, Martinez-Salamero, "Steady-State Analysis of Inductor Conduction Modes in the Quadratic Boost Converter," IEEE Transactions on Power electronics, vol. 32, no. 3, 2017.

[22] Mamun M. Al, Sarowar G., Md. Ashraful Hoque, Mehedi " High Gain Non Isolated DC-DC Step-up Converters Integrated with Active and Passive Switched Inductor Networks, "International Journal of Power Electronics and Drive Systems (IJPEDS), vol. 9, pp. 679-689, 2018.

[23] P. Yang, J. Xu, G. Zhou, S. Zhang, "A new quadratic boost converter with high voltage step-up ratio and reduced voltage stress", Proceedings of The 7th International Power Electronics and Motion Control Conference, vol. 2, pp. 1164-1168, June 2012.

[24] Alexandru Bitoleanu; Mihaela Popescu, Shunt Active Power Filter; Overview on the Reference Current Methods Calculation and their Implementation, 4th International Symposium on Electrical and Electronics Engineering (ISEEE 2013), pp. 1-12, 2013.

\section{BIOGRAPHIES OF AUTHORS}

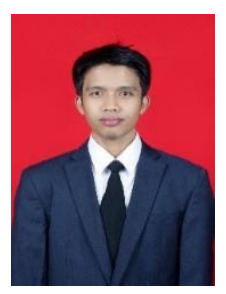

Moh. Jauhari received bachelor of Engineering (Electrical) from Institut Teknologi Sepuluh Nopember (ITS) Surabaya, Indonesia In 2015. In 2017, he received his Master degree from ITS, He joined POLTERA as lecturer in 2017.

Email: mohjauhari51@gmail.com

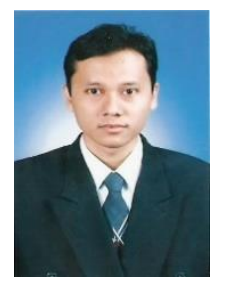

Dedet Candra Riawan received the Bachelor Degree in Electrical Engineering from Sepuluh Nopember Institute of Technology (ITS), Indonesia in 1999 and joined ITS as lecturer in 2000. He received his $\mathrm{PhD}$, and Master Engineering degree from Curtin University of Technology, Australia, in 2006 and 2010 respectively. His interest of research is in power electronics and its application in renewable energy.

Email: dedet.riawan@ee.its.ac.id

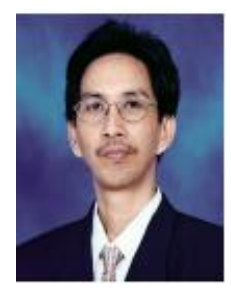

Mochamad Ashari recieved his bachelor degree from Institut Teknologi Sepuluh Nopember (ITS) Surabaya, Indonesia in 1989 and joined ITS as lecturer in 1990. In 1998 and 2001, he received his Master and $\mathrm{PhD}$. degrees from Curtin University, Australia. He became Professor to the Department in 2009. His research interests include applications of power electronics for grid systems, power quality, and renewable energy. He has received research grants from many institutions including ABB, JICA-Japan, Indonesia government.

Email : ashari@ee.its.ac.id 